\title{
The Higher Educator as “Intellocrat": The Odyssey of Carleton Stanley
}

\author{
Barry Cahill
}

"I've always been rather proud that we had at least one University president in Canada with genuine intellectual ideals.” - Frank Underhill, 1945

The intellectual history of Canada in the twentieth century is not peopled with university presidents. While many made a mark on their universities, few had an impact on higher education generally and fewer still affected the world outside academe. Probably there was only one such-Sir Robert Falconer-president of the University of Toronto from 1907 to 1932 and an authoritative public intellectual of the first rank. ${ }^{1}$ Few intellectuals became university presidents or cared to do so. In Canada, university presidents were clergymen (as was Falconer), professors, bureaucrats, academic deans, defeated politicians, British expatriates, and retired generals. Likewise, the historiography of higher education in Canada is not overweighted with studies of the university president. Those that exist treat the university presidency (or presidencies) biographically, as an episode in the career of the university president concerned, or institutionally, as an episode in the history of the university concerned.

This article examines the ideas and influence of one uniquely atypical Canadian university president during depression and war.

1 See James G. Greenlee, Sir Robert Falconer: A Biography (Toronto: University of Toronto Press, 1988); Michael Gauvreau, "Presbyterianism, Liberal Education and the Research Ideal: Sir Robert Falconer and the University of Toronto, 1907-1932,” in The Burning Bush and a Few Acres of Snow: The Presbyterian Contribution to Canadian Life and Culture, ed. William Klempa (Ottawa: Carleton University Press, 1994), 39-60. Falconer is the only Toronto president to be granted his own chapters in the official history: Martin Friedland, The University of Toronto: A History (Toronto: University of Toronto Press, 2002). On this subject generally see Richard A. Posner, Public Intellectuals: A Study of Decline (Cambridge, MA, and London: Harvard University Press, 2001).

(C) Historical Studies in Education/Revue d'histoire de l'éducation 14, 1 ( 2002): 67-91 
Carleton Stanley (1886-1971), an early graduate of Falconer's Toronto-and a protégé of Falconer-served as president of Dalhousie University from 1931 to $1945 . \quad$ Part professor and professional educator, part businessman, part journalist, and part scholar, Stanley, throughout his career, was a public intellectual distinguished (unlike Sir Robert) by his predilection for radical criticism.

Carleton Stanley strove to be the Canadian Matthew Arnold, and his critique of the Canadian experience was no less searching than Arnold's in Culture and Anarchy, which inspired it. ${ }^{2}$ Despite his contemporaneous importance and controversialness, however, Stanley as yet has no place in Canadian intellectual history. He does not figure in the writings of Berger, Ferguson, McKillop, Owram, or Taylor, ${ }^{3}$ though his ideas and experience are grist to their mill. Of the "three wise men" of the fabled University of Toronto graduating class of 1911 - Frank Underhill, Charles Norris Cochrane, and Stanley - it is invariably Stanley who is left out of consideration. Unlike Cochrane, he did not publish a great work of intellectual history; ${ }^{4}$ unlike Underhill, he did not survive a campaign to remove him from his university on account of his radical views. Yet no less a figure than Arthur R.M. Lower (who

2 On this subject generally see Patricia Jasen, “Arnoldian Humanism, English Studies and the Canadian University,” Queen's Quarterly 95, 3 (1988): 550-66. Though Jasen does not mention him, Stanley was the prototype of the Arnoldian humanist in the Canadian university. Stanley’s Alexander Lectures in English at the University of Toronto in 1938 dealt with Arnold.

3 Carl Berger, The Writing of Canadian History: Aspects of English-Canadian Historical Writing since 1900, 2nd ed. (Toronto: University of Toronto Press, 1986); Barry Ferguson, Remaking Liberalism: The Intellectual Legacy of Adam Shortt, O.D. Skelton, W.C. Clark and W.A. Mackintosh (Montreal \& Kingston: McGill-Queen's University Press, 1993); A.B. McKillop, Contours of Canadian Thought (Toronto: University of Toronto Press, 1987); Doug Owram, The Government Generation: Canadian Intellectuals and the State 1900-1945 (Toronto: University of Toronto Press, 1986); and Charles Taylor, Radical Tories: The Conservative Tradition in Canada (Toronto: Anansi, 1982). Berger’s chapter on Underhill, “History as Political Criticism” (pp. 54-84) could just as easily have been written about Stanley ("a friend”), who is mentioned in passing on page 59. Taylor's chapter, "Clear Grit," deals with Goldwin Smith and Frank Underhill: pp. 159-75. For a good critical analysis of the literature see Clarence Karr, "What Happened to Canadian Intellectual History?” Acadiensis 18, 2 (1989): 158-74. 4 His magnum opus, "Europe and Non-Europe, 1500-1900" [post-1953], a radical critique of Eurocentrism and imperialism, was so many years ahead of its time that it failed to find a publisher. 
knew him well) counted Stanley among those luminaries "having had their say, and a good say, in the building of modern Canada." 5 To paraphrase Philip Massolin, Stanley was a Canadian intellectual in the liberal tradition who, in the interwar years, rose to greet the challenge of modernity. ${ }^{6}$ He scarcely deserves the oblivion to which the odium academicum has consigned his memory.

Despite striving to be the Canadian Matthew Arnold, Carleton Stanley rather succeeded in becoming a latter-day Goldwin Smith. No critic of his generation was closer to Smith in inspiration than Stanley, whose undergraduate years at the University of Toronto coincided with the last few years of Smith's life. ${ }^{7}$ In his convocation address in 1940, Stanley was to point to Smith as the archetype of homo academicus. "Goldwin Smith," he wrote,

much derided for some of his opinions and prognostications, is also...a landmark. A humane man, he was troubled not merely by European cruelties to nonEuropeans, but also by the miseries inflicted by British capitalists on their factory workers. In many ways he was a "radical" and "anti-imperialist," to use his own terms to describe himself. He abominated Joseph Chamberlain, and deeply lamented the destruction of the Dutch Republics in South Africa, and British bad faith in the whole matter. ${ }^{9}$

5 Arthur R.M. Lower, My First Seventy-Five Years (Toronto: Macmillan, 1967): 50. 6 Philip Massolin, Canadian Intellectuals, the Tory Tradition, and the Challenge of Modernity, 1939-1970 (Toronto: University of Toronto Press, 2001). Though Stanley plays no part in this impressive study, his ideas appear on every other page. He was a critic of science as technology long before 1939, and of the reduction of education to training, professional or otherwise, long after. He also resisted the false modernization of higher education, as in the development of social science as a third way reconciling the supposed extremes of, and polar opposition between, science and the humanities.

7 Though Stanley was by no means an uncritical follower of Smith, he particularly admired the latter's great Report from the royal commission on the University of Toronto, issued in 1906, when Stanley was an undergraduate.

8 “178 Graduates Receive Degrees At Dalhousie University Convocation,” Halifax Herald, 15 May 1940.

9 Dalhousie University Archives (DUA), Carleton Stanley papers, MS-2-163, mfm: Stanley, “Europe and Non-Europe,” 263. 
Like Smith, Stanley was a writer, journalist, and controversialist. ${ }^{10}$ Like Smith, Stanley also held both a first-class honours BA in literae humaniores and an MA from Oxford; carried off a series of prizes in classics; and "planned to write some seriously scholarly works, ${ }^{11}$ but this goal proved incompatible with his intense interest in contemporary affairs.” As Smith had used his Oxford chair, so Stanley used his Dalhousie presidency to engage in controversies over political and educational questions. What Ramsay Cook says of Smith is equally true of Stanley: "Although he was undoubtedly a stimulating and devoted lecturer and tutor, he showed no interest in original research and published nothing of scholarly merit...He was a man of letters, not a research scholar." More importantly, Stanley was a free-trader and antiimperialist. ${ }^{12}$ He was also a "talented and acerbic political and literary critic [who hurled] his jeremiads ” at a world that was failing to liberalize. Goldwin Smith’s example encouraged Stanley to get involved in the municipal reform movement in Toronto. Like Smith, Stanley promoted teacher education. Like Smith, for all of Stanley's "breadth of knowledge and interest, [his] overriding concern was the contemporary world.”

In his time Carleton Stanley was one of Canada's most prominent and progressive educationists. An alumnus of both the classics and the English and history honours courses at the University of Toronto, ${ }^{13}$ Stanley went on to do a second BA at Oxford, where he achieved a First in Greats ${ }^{14}$ and became the first

10 This paragraph and those following are based on (and quote) Ramsay Cook, "Smith, Goldwin,” Dictionary of Canadian Biography, Volume XIII, 1901-1910: 968-74. 11 Among them, books on Samuel Butler and Greek science; on both topics he published important articles.

12 On the former see "A Defence of Free Trade in Britain," Montreal Gazette, 20 Feb. 1924; Canada's Peculiar Advantages in Foreign Trade; How These Are Thwarted By Our Tariff (Montreal: [n.p.], 1925), and DUA, Stanley papers, file B-28, Carleton Stanley to E.W. Beatty, 22 Feb. 1935 (referring to his articles for the Manchester Guardian, written between 1913 and 1916).

13 On this subject generally see Patricia Jasen, "Educating an Elite: A History of the Honour Course System at the University of Toronto,” Ontario History 81, 4 (1989): 26979.

14 Literae humaniores: the honours course in classics, philosophy, and ancient history. 
Canadian to be offered a tutorial fellowship. ${ }^{15}$ While at Oxford he began to write for the Manchester Guardian (the leading Liberal daily), and, before leaving England, was hired as the newspaper's first Canadian correspondent. He continued in this role during his three years as lecturer in English at Victoria University in the University of Toronto. Having become engaged in 1914 to the eldest daughter of William John Alexander, professor of English at University College, Stanley abandoned academic life in 1916 and went to work as a commercial traveller and sales agent for a Toronto textile manufacturer. Moving to Montreal to manage his employer's eastern Canadian sales, he settled in the Town of Mount Royal and, in 1921, went into business for himself. In 1925 he returned to academe as associate professor of classics at McGill, becoming, in 1930, assistant to Principal Sir Arthur Currie, and, in 1931, president of Dalhousie University.

A “new” liberal à la Leonard Trelawney Hobhouse, ${ }^{16}$ Stanley was in search of a via media between socialism and capitalism. He was less a social democrat than a radical liberal who believed in economic progress based on equality of opportunity and social justice. What interested Stanley about the liberal-democratic imperialism of Lionel Curtis and the Round Table movement (in which he became involved while at Oxford) was democracy and liberalism, not imperial co-operation. ${ }^{17}$ Believing that the Empire should benefit Canada rather than vice versa, Stanley was by no

15 In the summer of 1913 he was offered, but declined, the post of fellow and tutor in Greek at Hertford College.

16 It was "the great L.T.H.," formerly an editorial writer for the Guardian, who interviewed Stanley and engaged him on behalf of the newspaper. See generally Peter Weiler, “The New Liberalism of L.T. Hobhouse,” Victorian Studies 16, 2 (1972): 141-61; see also Reba N. Soffer, "Liberalism and the Liberal Attitude in Early Twentieth Century England" (Ph.D. diss., Radcliffe College, 1962).

17 On this subject generally see James Eayrs, “The Round Table Movement in Canada, 1909-1920," Canadian Historical Review 38, 1 (1957): 1-20; Carroll Quigley, “The Round Table Groups in Canada, 1908-1938,” Canadian Historical Review 43, 3 (1962): 204-24; Christopher R.J. Rickerd, “Canada and the Elliptical Round Table, 1908-1917: Deciding the Fate of Imperial Federation” (A.B. honours thesis, Harvard University, 1995), and Rickerd, “Canada, the Round Table and the Idea of Imperial Federation," in The Round Table, The Empire/Commonwealth and British Foreign Policy, ed. Andrea Bosco and Alex May (London: Lothian Foundation Press, 1997), 191-221. 
means a conventional imperialist. ${ }^{18}$ As a young teenager during the South African War he had been kicked in the shins by schoolyard bullies for refusing to condemn to death the Boer leader, Paul Kruger. Even then, young Stanley must have instinctively shared Goldwin Smith's anti-imperialism and opposition to Canadian participation in the "Boer" War. ${ }^{19}$

As a critic, Stanley ranged widely over the entire field of society and culture, both national and international, covering not only literature-his primary academic and personal interest-but also government and politics, economics, history, and philosophy. It was at Dalhousie University in the 1930s that Stanley, galvanized by the rise of European fascism, reached his zenith, and it was there that his vision of the supremacy of the university president as the teacher of teachers brought about his downfall, towards the end of the Second World War. ${ }^{20}$ Radical professors were barely tolerated by university boards. Radical presidents were not tolerated at all, either by boards or by other university presidents. For Stanley the freedom, indeed the obligation, to pronounce on controversial public issues affecting the world outside and beyond academe was the very essence of academic freedom. ${ }^{21}$ Academic freedom was an amalgam of the fundamental freedoms of thought and speech,

18 "I am not an imperialist in the common sense of that word," Stanley told a Canadian Officer Training Corps banquet in April 1937; DUA, Dalhousie University staff files, MS-1-3, file Sta 478. Nor does he fit the proto-nationalist-cum-patriot model articulated by Carl Berger in The Sense of Power: Studies in the Ideas of Canadian Imperialism, 1867-1914 (Toronto: University of Toronto Press, 1970). See also Colin M. Coates, ed., Imperial Canada, 1867-1917 (Edinburgh: University of Edinburgh Centre of Canadian Studies, 1997), 78-107. Stanley was far more interested in England per se than in the British empire, and viewed Canada as being in the pre-national stage of its development as an Anglo-American state. Stanley's “imperialism" placed more emphasis on the metropolitanism of empire than on the imperium.

19 See generally Robert J.D. Page, "Canada and the imperial idea in the Boer War years,” Journal of Canadian Studies 5, 1 (1970): 33-49.

20 The definitive account is P.B. Waite, The Lives of Dalhousie University, Volume Two, 1925-1980: The Old College Transformed (Montreal \& Kingston: McGill-Queen's University Press, 1998), 112-38; cf. Michiel Horn, Academic Freedom in Canada: A History (Toronto: University of Toronto Press, 1999), 178-81. See also Barry Cahill, "Dismissal of a President: The Ordeal of Carleton Stanley," Acadiensis 31, 1 (2001): 76102.

21 Horn, Academic Freedom, 318. 
and, more importantly, a necessary condition of the university's very existence.

Stanley's advocacy of academic freedom was therefore far from disinterested or impersonal and cannot be separated from his internationalism and early and outspoken anti-fascism. He was among those "growing numbers of prominent Canadians" who, according to Frank Abbott, "as the decade of the 1930s drew to a close...began to equate the defence of academic freedom with the defence of democracy itself."22 For Stanley, the defence of academic freedom was of a piece with the attack on European fascism. No Canadian university president spoke out against fascism before Stanley and none supported so outspokenly the Republican side in the Spanish Civil War. His ultramontane view of academic freedom as an absolute privilege, a sort of Kantian categorical imperative, lent credence to the supposition that his own dismissal in 1945 was a violation of it. Stanley was always ready and willing to make a last stand on academic freedom, which for him was why the university was, and had to remain, "a bulwark of freedom." 23 The Second World War thus became for Stanley a life-and-death struggle for the survival of both the idea and the reality of the university. Suffice to say, such views were not shared by other Canadian university presidents nor by the boards to whom they — and he-were answerable.

Academic freedom was pre-eminently "free speech in the form of comment on public events”- which, as Michiel Horn points out, "could be dangerous"; ${ }^{24}$ for Stanley it was to prove fatal. For him, the university president was the supreme pedagogue, the teacher of social justice. The president of the university taught academe as a whole and the community at large. Stanley's addresses to the university at the beginning of each academic year and to a wider public at convocation, not to mention his New Year's messages in the Halifax dailies, were state-of-the-world commentaries that

22 Frank W.C. Abbott, "The Origin and Foundation of the Canadian Association of University Teachers” (Ph.D. diss., University of Toronto, 1985), 96.

23 Title of an address delivered over the national network of the CBC, 5 Jan. 1940.

24 Horn, Academic Freedom, 183. 
attracted much attention and some controversy. ${ }^{25}$ Indeed it was his perception of his role and responsibility as the public intellectual, a proconsular idea man, that prompted Stanley, quite unlike his socialistic friends Underhill and F.R. Scott, to steer well clear of partisan politics. ${ }^{26}$ Stanley's friends included not only the socialist leader, James S. Woodsworth, and social democrats like Percy Corbett, ${ }^{27}$ Francis Hankin, and Terence W.L. Macdermot, ${ }^{28}$ but also tory-capitalists like Sir Edward Beatty ${ }^{29}$ and J.M. Macdonnell. ${ }^{30}$

Prior to leaving academic life in 1916, Stanley confined his critical writing largely to history and literature. His first major essay in social criticism appeared in University Magazine in February 1919. "Self Catechism" was a sustained attack on Canadian newspapers, ${ }^{31}$ municipal government, and universities. Animadversions such as, "our national passion for mendacious and complacent self eulogy with regard to all departments of our government and many things not directly connected with government," were intended to attract attention-and they did. ${ }^{32}$

25 The texts of Stanley's numerous addresses and lectures, most of which were printed or published, are to be found in series D of the Stanley papers at DUA and in his staff file: DUA, MS-1-3 file Sta 478. Copies of the president's address to the university at the beginning of each academic year were sent to all alumni.

26 'I am so constituted as to be 'between sizes' in politics. I could never admire either of our two parties to the extent of belonging to either, nor could I ever dislike either of them sufficiently to prevent my being on a good footing personally and socially, with some of the war-horses on both sides”: DUA, Stanley papers, file B-25, Stanley to C. Harold Hale, 21 Nov. 1933.

27 Sometime dean of law at McGill; on Corbett and academic freedom, see Horn, Academic Freedom, pp. 117-18. Corbett, a Maritimer by birth and a Rhodes scholar, had also been considered for the presidency of Dalhousie in 1931. Corbett's biography is being written by Kathy Fisher.

28 McGill colleagues and friends of Stanley; they co-authored Recovery by Control: A diagnosis \& analysis of the relations between business \& government in Canada (Toronto: J.M. Dent, 1933).

29 Chair and president of Canadian Pacific, and chancellor of McGill University.

30 Chair of the board of Queen's University, and Canadian secretary of the Rhodes Trust.

31 In March 1920, Stanley severely criticized the Canadian press for its biased coverage of the sedition trials of the leaders of the Winnipeg general strike: "Distortion of News," Québec Chronicle, 19 Mar. 1920.

32 Carleton W. Stanley, "Self Catechism,” University Magazine 18, 1 (1919): 26. “I have been violently attacked in the Saturday Night over it, and 'let down' elsewhere as a youthful, inexperienced writer etc.”: National Archives of Canada (NA), Frank Underhill papers, MG30, D204, vol. 2, Stanley to Underhill, 3 Apr. 1919. The source of the violent attack was Hector Charlesworth, "Reflections,” Saturday Night, 29 Mar. 1919. 
Stanley added decisively to his reputation as a fearless critic in January 1923 with a lacerating jeremiad, "Spiritual Conditions in Canada," which appeared in Hibbert Journal, a British quarterly review of religion, theology, and philosophy. ${ }^{33}$ Despite its ironic title, Stanley's essay has nothing to do with spirituality in the usual sense; indeed, it suggests that the conditions for spirituality (by which Stanley meant intellectual culture) did not exist in Canada. Stanley's lament for the national myth of progress was, in the first instance, a ringing denunciation of the hypocrisy, materialism, and capitalist bias of organized religion. Nor were the universities spared; "university education in Canada has swiftly and silently come to be the prerogative of the well-to-do." Universities, like schools, churches, and the newspapers, were in thrall to the business capitalists. "Right down to our elementary schools," Stanley observed, "the very text-books of which are printed and stamped by the octopus firm [Eaton's], there is one lesson taught, one gospel preached: 'There is no God but money, and Canada with its unparalleled natural resources is the most God-fearing country in the world'., 34

Seventy-five years before the satirists of Double Exposure, adopting the persona of Lucien Bouchard, reminded Canadians that Canada is not a real country, Stanley was pointing out that Canadians have no "really independent institutions of any kind.",35 In the area of national politics, Stanley's endorsement of the platform of the Progressive Party, which scored a notable success in the federal election of 1921, was as close as he ever came to political partisanship. One of the most remarkable features of "Spiritual Conditions in Canada" is that Stanley, despite the antiCatholicism imbibed through his strict Baptist upbringing, warmly admired and appreciated les Québécois. ${ }^{36}$ Nevertheless, the spectacle of a Torontonian-worse, a graduate of the University of

33 “Spiritual Conditions in Canada,” Hibbert Journal 21 (1923): 276-86. On the impact of this critique see Sandra Dwja, The Politics of the Imagination: A Life of F.R. Scott (Toronto: McClelland \& Stewart 1987), 70. See also “A Canadian Jeremiah,” Manitoba Free Press, 2 Feb. 1923.

34 Stanley, "Spiritual Conditions" [1923], 280.

35 Ibid., 281.

36 Stanley, who was bilingual, numbered among his friends the literary critic Mgr. Camille Roy, dean of French-Canadian letters. 
Toronto_-attacking Canada in a British periodical was offensive to many who read it. ${ }^{37}$ Canadians did not want to be told that they were vulgar, ignorant, and superficial—and, withal, complacent about it; or that Canada had no art, literature, or culture worthy of the name. The article, which received extensive coverage in the Canadian press, caused a sensation, and Stanley became a pariah overnight. "The publication of my article in the January Hibbert [1923],” Stanley wrote,

was perhaps as instructive to myself as to any of my readers. I expected, as I received, a chorus of abuse from newspapers, pulpits, and some university dignitaries...[yet] not only have academic friends given me kind words, and one or two newspapers, and several preachers...but I have had hundreds of letters from all over the country and from all sorts of people, most of whom were quite unknown to me. Not all of these were in entire agreement with me, but while many thought the stipple work in my picture too heavy, there were many who thought it not dark enough. ${ }^{38}$

Together with his reply to his detractors, ${ }^{39}$ published under the same title the following year, "40 "Spiritual Conditions" established Stanley's credentials as an incisive commentator on Canadian affairs. Unlike most other Canadian critics of Canada, Stanley's

37 “Canada Hit In English Paper By Victoria University 'Grad'; Man Educated in Toronto Has Bitter Things to Say About His Native Land-Carleton W. Stanley, of Montreal, Has Many Faults to Find With Conditions in Canada,” Toronto Evening Telegram, 15 Feb. 1923. The Telegram reprinted Stanley's article nearly verbatim. The article almost eliminated Stanley from consideration for the McGill professorship to which he was appointed two years later; McGill University Archives, Office of the Principal records, RG2, G43 (file "Dalhousie University”), Dean of Arts (Laing) to Principal (Currie), 14 May 1923.

38 Stanley, “Spiritual Conditions in Canada,” Hibbert Journal 22 (1924): 360.

39 For particularly adverse comment, see the article by the principal of Manitoba College (University of Manitoba), the Reverend John MacKay, a Presbyterian minister: “Spiritual Conditions in Canada: A Reply,” Hibbert Journal 21 (1922-1923): 773-85. See also Millege L. Bonham Jr., "Spiritual Conditions in Canada Viewed from Across the Border,” Hibbert Journal 21 (1922-1923): 579-84; “Canadian 'Materialism',” New York Times, 17 June 1923, section 2.

40 Stanley, “Spiritual Conditions in Canada,” Hibbert Journal 22 (1924): 360-74. 
radicalism enabled him to make the transition from criticism to hypercriticism in the 1920s, not the 1930s. For Stanley the folly and materialism of the 1920s was leading inexorably to economic disaster in the next decade. The 1920s, moreover, were not the period of the formation of Canadian national consciousness ${ }^{41}$ because there was no "nation" around which a national consciousness could coalesce.

Stanley resumed his critique in 1924 in an article published in the Dalhousie Review, successor to the defunct University Magazine. In "The Cult of Mediocrity in Canada," 42 Stanley argued that democracy in Canada meant the political rule of tariffprotected millionaires alongside the cultural hegemony of the working class. The Canadian form of government was the worst that democracy had to offer-a perversion of the ancient Greek ideal. "We, with the most artificial geography a State has ever had, have drugged whole portions of our community into [an] economic coma." "43 Stanley was a free-trader who viewed protectionism in any form as the antithesis of sound economics; rather than fostering economic growth through international trade, it fostered oligopolistic wealth-creation. The rich got richer and the poor, poorer. The high protective tariff, which both the Conservative Party and the Liberal Party (then in power) supported, had, according to Stanley, "directly resulted in Americans owning a very large share of our industries." 44 For him the possibility of Canadian nationhood, from which a national consciousness might emerge, was being undermined by the Canadian form of democratic government-rule not by the people, but by an unrepresentative and irresponsibly partisan parliamentary dictatorship. "The student of history and politics," Stanley concluded, "is obliged to think it an odd thing that we should give the title democracy to our Canadian system."45

41 See generally Mary Vipond, "National Consciousness in English-Speaking Canada in the 1920s: Seven Studies" (Ph.D. diss., University of Toronto, 1974).

42 Dalhousie Review 4, 1 (1924): 42-51.

43 "Cult of Mediocrity," 49.

44 Ibid.

45 Ibid., 50 . 
In January 1929 Stanley became a regular contributor to the quarterly Dalhousie Review. His eight features ("Topics of the Day”) consisted of journalistic vignettes and op-ed pieces covering a range of subjects so broad as to show him at his critical and didactic best. By December 1930, however, Stanley’s heavy administrative responsibilities as assistant to the absent principal of McGill, in addition to his regular teaching duties as professor of Greek, compelled him to abandon journalism. Coincidentally, Dalhousie University at the time was searching for a new president. Approached in the spring of 1931, Stanley declined to be considered for the post; approached again, he reluctantly changed his mind and accepted the offer. ${ }^{46}$

The presidency of Dalhousie was a challenge that appealed to Stanley because he believed that the university, despite being a private institution, could be to Atlantic Canada what the University of Toronto was to Ontario-the regional university. ${ }^{47}$ His inauguration, in October 1931, was a great public spectacle, at which even the prime minister, R.B. Bennett-a member of Dalhousie's board-spoke by radiotelephone from Ottawa. In his inaugural address, Stanley set the tone for his presidency by issuing

46 P.B. Waite quite properly devotes three full chapters of his official history of Dalhousie University to Stanley's presidency: Old College Transformed, pp. 51-111. His characterization of Stanley as the "philosopher king" (an allusion to Plato), however, does justice neither to Stanley's views nor to his view of himself. Stanley was less an anti-modernist than a post-modernist who wanted to apply ancient Greek wisdom to solving modern world problems. See also Paul Axelrod, "Moulding the Middle Class: Student Life at Dalhousie University in the 1930s,” Acadiensis 15, 1 (1985): 84-122. Neither Waite nor Axelrod addresses Stanley's radicalism, directly or indirectly. Axelrod, equating Stanley's promotion of the classics with reactionary attitudes towards higher education, mistakenly dismisses him as a "traditionalist": Making a Middle Class: Student Life in English Canada during the Thirties (Montreal \& Kingston: McGillQueen's University Press, 1990), 43. See also Axelrod, "Student Life in Canadian Universities: The Lessons of History," Canadian Journal of Higher Education 20, 3 (1990): 24. Far from being a pedantic fuddy-duddy, Stanley was a believer in holistic self-education for whom constructive leisure ("school” in the classical sense) was much more important than reading about books.

47 He shared the view of the Carnegie Corporation of New York, whose famous 1922 bulletin, Education in the Maritime Provinces (Learned-Sills Report), considered Dalhousie University to be the only "real university in this area": DUA, Stanley staff file (Sta 478), Stanley to J.C. Webster, 9 Feb. 1939. For Stanley the other universities and colleges in the Maritimes-the University of New Brunswick excepted-were but glorified high schools. 
a solemn warning against "the besetting sin of academies and the academic mind, namely a dogmatic and prejudiced conservatism.."48 Stanley's opinion was "that economic and social changes have followed one another so swiftly in this country that we have not adapted our institutions to them." 49 His solution was to "rehumanize" economic and social institutions by rehabilitating the universities and re-educating them in their responsibility to the community. It was the very inversion of ivory-towerism. The central idea of Stanley's liberal intellectualism was that humanistic learning, which comprehended and integrated "arts" and "science," lay at the heart of human progress. Stanley was not an early Victorian liberal for whom the balance of the humanities and the sciences had somehow to be preserved against the advancement of learning, but a Platonist for whom the whole of knowledge was a dynamic unity.

Just how unconventional a university president Stanley was going to be was evident from his address to Dalhousie's freshman class in September 1931. "Frankly," he remarked, "I should wish to talk to you of other things; of some of the new books, for example, or politics, or the Gold Standard.” And, characteristically, he did not refrain from doing so.

The world has fallen on evil days, and I cannot conscientiously omit to mention that. You must all know, if you know anything, that tens of thousands of your fellow-citizens in Canada are this very morning on the brink-I was going to say "on the brink of starvation"-but let me put it this way: on the very precipiceedge of losing their self-respect, on the very thin edge which separates hope and despair. For all of us that is a terrible state of affairs. ${ }^{50}$

48 The Inauguration of Carleton W. Stanley as President of Dalhousie University...Capitol Theatre, Halifax Friday, Oct. 9, 1931 (Halifax: Dalhousie University), 12 ("Inaugural Address").

49 Ibid., 18.

50 “A University and its Students," University of Toronto Monthly (Dec. 1931): 116; also published as "Trustees of the Ages," World Wide: Canada's Weekly Review (Montreal), 7 Nov. 1931. 
In Canada in 1931 such statements were not made by university presidents to an audience of first-year students. "Nor did it make it easier for me to stir the air of the place," Stanley recalled some years later, "when I was told that none of my predecessors had ever been in the habit of addressing the university." For Stanley the university president was not merely the chief executive officer but also, and perhaps more importantly, the presiding teacher. The professors taught the students; the president taught both.

I was not trying to make a great noise, myself, but it did seem to me necessary to speak to the heart and mind of every one in the audience, to remember that some of them had just entered the Bell jar, and that all of them would sooner or later be outside it, and forced to speculate on Manchuria, ${ }^{51}$ and unemployment, and class war within the state as well as international upheavals, to say nothing of revolution in ethics and science. ${ }^{52}$

Like Periclean Athens, Halifax finally had its Socrates and he wasted no time endeavouring to subvert the youth while confounding their parents. In November 1931, responding to the toast to Canada at a North British Society banquet in Halifax, Stanley deplored the harsh prison sentences recently meted out to the Toronto Communists. ${ }^{53}$ In October 1932, having gained a suitable venue in the shape of the new university gymnasium, Stanley made permanent his "self-imposed custom” of addressing

\footnotetext{
51 Invaded by the Japanese in Sept. 1931.

52 DUA, Stanley papers, file D7, President's address, 1 Oct. 1940.

53 The text of Stanley's remarks is in his staff file: DUA, Sta 478. Unlike his mentor Sir Robert Falconer, whom he counselled during the furore over the letter by the sixtyeight Toronto professors protesting state harassment of the alleged Communists, Stanley did not believe that university presidents, much less university teachers, should refrain from commenting publicly on controversial public issues. See Stanley to Falconer, 22 Dec. 1931; quoted in Greenlee, Sir Robert Falconer, pp. 299-300; see also Michiel Horn, “'Free Speech Within the Law': the Letter of the Sixty-Eight Toronto Professors, 1931,” Ontario History 72, 1 (1980): 27-48.
} 
a general assembly of faculty and students at the opening of each academic year. ${ }^{54}$

By 1933 Stanley was adjudging the worst of the "worldwide economic, social and political maladjustments" to be German fascism. He had read Hitler's Mein Kampf (in the original) "and knew the poison in it."55 Though neither appeaser nor warmonger, Stanley was a multilateral disarmer rather than a pacifist. As late as 1936 his anti-war message on Peace Day was the more profound for being subtle. He did not oppose war so much as those who advocated it; he did not oppose rearmament so much as the private, for-profit manufacture of and traffic in munitions. ${ }^{56}$ Until war finally came and well beyond, he continued to believe that fascism could have been defeated without war if it had been resolutely opposed from the start. Addressing the university in October 1933, a few months after Hitler had become dictator of Germany, Stanley stated,

I think I should be doing much less than my duty if I did not pause to invite you all, this morning, older and younger, to reflect on the terrible catastrophe that has overtaken academic life in Germany...[A]s a learned society I believe we should realise, and be warned, that what has happened in Germany is a threat and a potent menace to intellectual freedom everywhere. ${ }^{57}$

Stanley was referring particularly to the new German policy of transforming the universities into purely Nazi institutions. "I spoke so emphatically, just five years ago," Stanley recalled in 1938, "because I had heard a man say in Halifax, "what the labouring classes in this country ought to have is a Hitler': and because there

\footnotetext{
54 “University Head Speaks To Students,” Dalhousie Gazette, 12 Oct. 1932; cf. "Student Body And Faculty Are Addressed," Halifax Morning Chronicle, 7 Oct. 1932. 55 DUA, Stanley staff file, Sta 478, President's address, Victoria University, 15 Oct. 1941.

56 DUA, Stanley papers, file D3, President's address on Peace Day, 20 Mar. 1936.

57 Academic Life; The President's Address at the Opening of the Session, 1933-34 (Halifax: Dalhousie University, 1933).
} 
were newspapers in this country who were condoning Hitler and Mussolini, and in the same selfish, money-bag spirit." 58

Stanley's intensifying opposition to fascism prompted him to articulate more clearly his idea of the university. Addressing convocation in the spring of 1935, he observed, "A university graduate who is interested neither in the affairs of his own community nor in the great world has not justified himself. Instead he has been a costly mistake." ${ }^{59}$ The burden of responsibility falling on university graduates was all the greater because freedom was a fundamental condition of the university's existence.

The question of questions today is whether tyranny and despotism are going to spread and engulf the world, or whether liberty will find, here and there, a citadel...If there be no freedom, there cannot really be universities, so for their self-preservation, the universities must stand for freedom. ${ }^{60}$

That same month, giving the address at the encaenia (convocation) of the University of King's College, Stanley deplored "the irrationality, the incurable stupidity of the human species," which had led to the assault on freedom now threatening both the university and the world. ${ }^{61}$ Man's unreason was particularly evident in economic mismanagement, and the latter in protectionism:

As for international trade, I myself have seen, over and over again, the bankruptcy and ruin of those who tried to conduct it. I have myself seen the price of a commodity imported into this country increased fourfold by stupid tariff regulations. I have seen goods rotting in a customs warehouse, which no one in this country manufactured, and which a dozen trades in this country were clamouring

58 ““Candle-Snuffers Of Freedom’ Scored in Address,” Halifax Herald, 5 Oct. 1938.

59 “Annual Closing Attended By 1500,” Halifax Herald, 15 May 1935.

60 Ibid.

61 Carleton Stanley, “The Incurable Stupidity Of The Human Species,” Saturday Night, 6 July 1935. 
to have. The prohibition of these imports was of course tantamount to the prohibition of our exports. This country, historically, economically, is designed for foreign trade. By our own human action we have done nearly everything to stifle foreign trade. ${ }^{62}$

By autumn 1935, Stanley, half in fun, whole in earnest, was exhorting the students to be something more than mere cultural revolutionaries:

I hear many of my coevals saying with alarm and dismay that youth today is revolutionary. I am not alarmed nor dismayed on that score. I should be if I thought that young men and young women were not revolutionary. My young friends, you should be. There is no other hope for the world. There are many things always to revolt and rebel against. Somewhere or other stupidity is always enthroned. Somewhere or other there is [sic] always wrongs to right. Somewhere or other there is going to be a wholesale revolt on the part of the youth in North America against what is offered them, by selfish, commercial interests, in the name of amusement and entertainment. Suppose you began a revolt here and now...Men and women who will accept the false for the true in music, will listen to those who advise that slavery be accepted in order that freedom may follow; they will listen to promises of twenty-five dollars a month for nothing except a vote. And so, I say, revolt and rebel. ${ }^{63}$

University graduates were to be the vanguard of world revolution because they were citizens of the world. Addressing the National Association of State Universities in Washington, DC, in November 1935, in his capacity as president of the National

\footnotetext{
62 Ibid.

63 "President Addresses Students On Opening Of New College Term," Dalhousie Gazette, 1 Nov. 1935.
} 
Conference of Canadian Universities, ${ }^{64}$ Stanley developed this theme of the university as world state:

We can remind ourselves in the beginning that the subject-matter with which we deal in the universities is international...Homer, Benedetto Croce, Archimedes, Einstein - none of these is a national figure. They are citizens of the world. But does it follow that the students of this raceless, timeless material are automatically becoming citizens of the world? ${ }^{65}$

Yet the universities would not be in a position to lay the intellectual foundations of internationalism until they themselves practised cultivating an international outlook. "We [in Canada] have become painfully aware that if we are to produce scholars and critics with the international outlook, the universities themselves will have to be considerably changed." $\$ 6$

Stanley endeavoured to show the community how a university could be a school for world citizenship and the university president a teacher of it. "More than once," he reminded convocation in 1936,

in speaking to the University from this platform, in the past three years, I have deemed it my plain duty to call attention to the relation between learning and liberty, and to warn my hearers that what is going on in Italy and Germany should be an awful example to us. More than ever to-day it is my duty to call attention to these things, for the monstrous assault on civilization has continued; liberties not only in these two countries but in other countries have been contracted, and, so far as I know, few

64 Now the Association of Universities and Colleges of Canada.

65 Carleton Stanley, "The Universities and the International Outlook," University of Toronto Quarterly 5, 2 (1936): 256.

66 Ibid., 259. 
newspaper editors in Canada, no public men except one, ${ }^{67}$ have lifted up their voices either in protest or in warning. ${ }^{68}$

In his sessional address the following October, Stanley made no bones about the moral turpitude of the Canadian government, appeasers avant la lettre:

A good question perhaps for a Canadian to begin with is why, when the Canadian member of the League of Nations committee ${ }^{69}$ in Geneva last November [1935] suggested that oil and gasoline be included in the embargo of over fifty nations against Italy, the Canadian government disowned him. Why did the Canadian government take the lead in permitting the export to Italy of the one commodity an embargo on which could have stopped the war against Abyssinia [Ethiopia] ${ }^{70}$

For Stanley, academic freedom was the assertion of that fundamental freedom that enabled universities to exist. He well understood that academic freedom was the reason why universities were among the first casualties of German fascism. Moreover, he practised what he preached. Thanks to Stanley, Dalhousie not only acted against fascism but also was the first to do so-while other Canadian university administrations were still obsessed with the "Bolshevik menace." The first “exile from Hitlerland” was Lothar Richter, who arrived in 1934 as Dalhousie's first professor of German and in 1937 became first director of Dalhousie's new Institute of Public Affairs. The second was Martin Silberberg (pathology), who also arrived in 1934 and remained until 1936. Addressing convocation in May 1936, Stanley proudly observed,

67 Possibly W.D. Herridge, former Conservative Prime Minister R.B. Bennett's brother-in-law and closest adviser and Canadian minister in Washington, 1930-1935. 68 DUA, Stanley papers, file D3, Convocation address, 12 May 1936; "Hitlerism And Fascism Assailed As 198 Get Degrees At Dalhousie,” Halifax Herald, 13 May 1936. 69 Walter Riddell.

70 DUA, Stanley papers, file D4, President's address, 1 Oct. 1936. 
Dalhousie has done something. It contributed to Lord Rutherford's fund for the relief of exiles as soon as that fund was opened. It has extended hospitality to exiles. It has refused like Oxford and Cambridge to participate in the celebrations of the University of Heidelberg. It has refused to have anything to do with the sending of athletes to [the Olympic] games in Germany. ${ }^{71}$

Stanley's opposition to fascism intensified greatly during, and because of, the Spanish civil war, from the outbreak of which in 1936 he was an outspoken supporter of the democratic republican government. When the Marxist Dr. Norman Bethune, whom Stanley had probably known in Montreal, spoke at Dalhousie in September 1937 about the work of the Canadian Blood Transfusion Corps, Stanley presided at the meeting and introduced the speaker. $^{72}$ It is not known whether Stanley was a member of the Canadian Committee to Aid Spanish Democracy, but his criticism of Britain's failure to oppose fascist intervention in Spain irritated the conservative establishment in Halifax. ${ }^{73}$

Unsurprisingly, Stanley's critique of fascism reached a crescendo in the autumn of 1938, when war threatened and Neville Chamberlain claimed to have achieved "peace in our time" by sacrificing Czechoslovakia to Hitler. Addressing the university in October, Stanley used very strong language while urging Dalhousie students to be leaders in the fight for freedom and tolerance:

71 "Hitlerism And Fascism Assailed."

72 See John Bell, "Exploring the Bethuniverse: When Bethune was at Dalhousie," University News (May 1976): 10-11. See also the attack on Stanley for agreeing with Bethune, in the Toronto Catholic Register, 4 Nov. 1937: "The accusation that they [the Nationalists] are bombing women and children in the name of religion is frequently made by Communists and a Communist [Bethune] recently lectured at Dalhousie on the Spanish Civil War and was introduced by Dr. Stanley.”

73 DUA, P.B. Waite (university historian research) papers; Laura K. Woolner, "Memories of My Father" [1991]. See also DUA, Stanley papers, file B35, Stanley to E.K. Brown, 1 Sept. 1936; Stanley papers, file D8, President’s address, 21 Oct. 1937; "Immortal Achievements For Canada Urged By President," Halifax Herald, 22 Oct. 1937. 
So freedom is one, and uniform. The enemies of freedom are multiform. The enemies of freedom are not only those sadistic monsters who gloat over torturing human flesh. They are all those respectable, proper, conventional, easeloving, tuft-hunting, must-be-in-the-swim people who will not listen to a distant call for help, if that call be inconvenient; who are nervous about expressing an opinion, or damning folly and injustice, until the "right people" have so expressed themselves; who want to serve God and Mammon at one and the same time; who have no real love and no undying hate. ${ }^{74}$

Nor did Stanley lose sight of the threat to academic freedom posed by the failure to resist fascist tendencies in liberal democracies. Debating the subject of academic freedom in Canada on the CBC's National Forum in December 1938, he again alluded to his prophetic utterances of October $1933 .{ }^{75}$ The war on the universities that had commenced in Germany in 1933 was accelerating in Canada in the shape of assaults on academic freedom. " "It is not wise," Stanley told convocation in May 1939, "to miss what is happening to the universities in Canada. Anyone who fails to see the dangers and threats to the existence of universities in Canada is indeed blind, blind in both eyes, blind in mind and heart."77

Stanley conceived the role of the university in fighting fascism as symbol and metaphor of a wider moral and intellectual struggle. "Here in the University," he stated in his sessional address in October 1939, shortly after war was declared,

74 ““Candle-Snuffers Of Freedom'...” The following month Stanley was among those prominent persons delivering speeches to a large anti-fascist rally in Halifax called by the local committee of the Canadian Jewish Congress to respond to Germany's Kristallnacht. "Persecution Of Jews Is Condemned; Halifax Mass Meeting Calls For Cessation Of Cruelties In Germany,” Halifax Herald, 21 Nov. 1938. For positive reaction to his speech, see “On, Stanley, On!” Sydney Steelworker, 3 Dec. 1938.

75 NA, F.R. Scott papers, MG30, D211, vol. 1 (“Academic Freedom, Clippings and Printed, 1935-1950”): Canadian Broadcasting Corporation, “NATIONAL FORUM as broadcast Dec. 18, 1938...”

76 See generally Horn, Academic Freedom, $88 f f$.

77 Dalhousie University, The President's Address. Convocation May 16, 1939, 1-2. 
we wage war, an endless, unremitting war...We wage war against intolerance, bigotry, cruelty, superstition - that you will readily understand. We wage war against injustice and methods of violence-that, too, you will easily understand. But we also fight relentlessly against many, many things which in some quarters are considered virtuous and respectable, and quite the proper thing...

In the first place we actually hate and wish to exterminate a comfortable majority of mankind-those who find it distasteful to think. Then again, though we are traditionalists in a certain sense, we despise convention and those who blindly observe the proprieties, and who wait to see what the majority are saying. We hate blunders and incompetence just as fervently as we hate a crime. $^{78}$

As the tide of war crested and turned, Stanley came to view the struggle against fascism abroad as equally one for the survival of the university at home. ${ }^{79}$ His report to the board of governors for 1941-42 described the tendency, accelerated since 1939, to change fundamentally the work of the university, a tendency that could destroy universities in the modern world. Stanley pointed out that Hitler's first action was to destroy liberal education from the ground up. He wondered whether Canadian universities, in their war on Hitler in Europe, were at the same time going to fight his battle for him in Canada. ${ }^{80}$

78 DUA, Stanley papers, file D6, President's address, 12 Oct. 1939; cf. "President Declares War,” Dalhousie Gazette, 13 Oct. 1939.

79 This is brought out particularly clearly in Stanley's war-time New Year's messages in the Halifax newspapers, one of which (unpublished) was entitled, "Is This the Time to Let a University Perish?”

80 Paraphrasing Dalhousie University, President's Report for the Year July 1st, 1941June 30th, 1942, 3-4, 9. Stanley had made a similar argument in trans-Canada broadcasts on 12 June 1939 ("The Supreme Importance of the University in the Present Juncture of World Affairs") and on 5 Jan. 1940 ("The University as a Bulwark of Freedom”), and was to reiterate it on the CBC National Forum, 13 Oct. 1942 ("Are the Universities a Bulwark of Freedom?”). See “Brilliant Defence of Liberal Education,” Dalhousie Gazette, 16 Oct. 1942. 
Stanley entitled the last of his sessional addresses, in October 1944, "Life and Education." By the time it was delivered, the governors' campaign to remove him was rapidly gaining momentum; less than four months later, he was fired. In his swansong, Stanley reprised a familiar theme, one that had overshadowed his presidency:

It became plain in 1933 that education and life were perishing in Germany, not because ignorant murderers had armed power, but because learning had folded its hands, murmuring:

"Creep into thy narrow bed,

Creep, and let no more be said!"81

At that time also it was plain to any educated man, that such an attitude could not be confined to Germany, and that everything worth living for was threatened, at least, in all parts of the world. ${ }^{82}$

Moreover, the threat to the survival of the university in postwar Canada persisted despite the looming defeat of fascism abroad. Just as the failure to act against international fascism early and decisively enough had led to tyranny and war, so the neglect and abuse of academic freedom had eviscerated higher education and compromised the integrity of the university. ${ }^{83}$ For Stanley, violations of academic freedom before and during the war foreshadowed the betrayal of humanism after it. ${ }^{84}$ The relationship between learning and liberty had been fatally undermined. A full

81 Matthew Arnold, “The Last Word.”

82 Dalhousie University, The President's Address At the Opening of the Session 194445, 6 .

83 Dalhousie University President's Address...1944-45, 6-7; see also J.V. McAree, "Higher Education Menaced In Canada," Toronto Globe \& Mail, 2 Nov. 1944.

84 On this subject generally see Carleton Stanley, "Remarks on the Discussion of the Future of the Arts Course," National Conference of Canadian Universities...Twentieth Meeting...1944, 60-62. Stanley well knew whereof he spoke. In 1940-41 his friend Frank Underhill was nearly dismissed from the University of Toronto, where he had taught history since 1927, for daring to suggest in an extramural speech that Canada's true interests as a North American nation lay with the United States rather than with Britain. The temper of the times is clear from W.E.C. Harrison, The Universities are Dangerous (London: Oxford University Press, 1941). 
generation before Northrop Frye-who, at the beginning of his career, held the same lectureship in English at Victoria College as Stanley had held at the beginning of his-Carleton Stanley articulated the liberal humanist vision of culture as freedom. ${ }^{85}$

Stanley shot his last bolt in the 1945 Dalhousie yearbook, where, ten years after his clarion call of 1935, he revisited the theme of revolution:

Now, the period since 1930, is a great revolutionary era in the history of man. It was an ancient saying that "revolution begins in hunger." All the economic historians agree in calling the period, 1840-1850, "The Terrible” Forties. Ireland, at that time, was not hungrier than Poland, Italy, or Spain. Yet with all the scientific knowledge at their disposal, the rulers of the world, in the 1930s, were unable to prevent destitution and starvation over much larger areas than the area which suffered in the 1840s.

We may be sure that Dalhousie will not find itself outside the vortex of this revolution....Your class, I venture to remind you, will not have done its full duty to Dalhousie merely by successfully performing your tasks here, and graduating. For years you have heard what Dalhousie stands for. It is still your responsibility to see to it in the future that this great university is not whirled about like a leaf, losing its tradition, and its soul. ${ }^{86}$

Its tradition was toleration and its soul freedom. Both had been compromised by the dismissal of the president four months earlier. For Dalhousie as an institution of higher learning, the year 1945 was indeed a year of revolution. Its president had sacrificed himself for the sake of the principle that the free university had right and reason to exist. "Until educated men of integrity,"

85 Graham Good, Humanism Betrayed: Theory, Ideology, and Culture in the Contemporary University (Montreal \& Kingston: McGill-Queen’s University Press, 2001), 88.

86 Dalhousie University, Pharos 1945: 5. 
Stanley wrote Underhill, "are willing to go to jail, \& suffer everything, there is no hope for this country." "87 Underhill had survived a determined assault on his academic freedom thanks to the principles for which Stanley had had to suffer martyrdom. If Frank Underhill was "the conscience of the university world" 88 after the war, then before and during and at the end of it, that conscience had been Carleton Stanley.

Stanley's efforts in the hungry and dirty 1930s to politicize Dalhousie students proved fruitless. ${ }^{89}$ Yet despite the fact that Stanley himself was decidedly a political radical, it was not his social liberalism but his faith in the superiority of the "Western Tradition" that drove his critique of how far Anglo-Saxon civilization, especially the Canadian variety, had diverged and deviated from the Greek ideal. Stanley never resolved the inherent contradictions between his liberalism and his intellectual elitism; between rule by the hoi polloi and rule by the best. In the end, Plato's republic — which in any case was not a democracy — was too good an idea to be true.

87 DUA, Stanley papers, file B75, Stanley to Frank Underhill, 2 Mar. 1945 (draft, unsigned).

88 Hilda Neatby, “Frank Hawkins Underhill 1889-1971," Proceedings and Transactions of the Royal Society of Canada ser. iv, vol. x (1972): 99.

89 On this subject generally see Waite, Old College Transformed, 311-12. The "student movement of the 1930s" largely passed Dalhousie students by; see Paul Axelrod's article of that title in Youth, University and Canadian Society: Essays in the Social History of Higher Education, ed. Paul Axelrod and John G. Reid (Kingston \& Montreal: McGill-Queen's University Press, 1989), 216-46. 